The axenic lambs were obtained by aseptic caesarian section in ewes after $\mathrm{I}_{4} 8$ to I 49 days of pregnancy. The seasonal oestrus cycle was palliated by synchronization of heats in order to obtain lambs all over the year. In addition, with the aim of knowing the dates of mating and parturition, we practised artificial insemination. In spite of this, it is still necessary to dispose of 2-3 pregnant females per caesarian section if the production is to be planified over the whole year.

Before the caesarian section, the left side of the abdomen was shaved, washed with soap and disinfected with iodine tincture. Thereafter the "surgical isolator " was placed against the side of the animal by means of the instant sterile drape surgical film. At the moment of the caesarian intervention, the sterile drape surgical film and the abdominal wall of the ewe were incised simultaneously. After extirpation and incision of an uterine horn, the lambs were withdrawn and placed in the "transfer isolator" in order to be reanimated.

Thereafter the animals were reared in balance cages ( 2 animals/cage). They were fed $a d l i b i-$ tum on whole cow milk, homogenized and sterilized at $\mathrm{I} 50^{\circ} \mathrm{C}$ for 2.4 seconds (UHT milk). At the sterilization the milk was filled into milk cans (50-100 1) and then transferred into the " rearing. isolator ", according to demands, by means of a sterile tubulation.

A control of the axenic state of the animals was made by means of bacteriological analysis of faeces samples, taken every third day. A range of 6 different media were inoculated with the faeces and then incubated at $37^{\circ} \mathrm{C}$ in aerobiosis and anaerobiosis. Up till now, only one contamination, due to an error of handling, has been recorded among the 5 lambs from 4 caesarian operations. The animals (generally the Limousin-Romanoff breed) were kept germ-free for a mean period of about 20 days and their weight gain was $230 \mathrm{~g}$ per day. Among these 5 lambs, one was slaughtered when leaving the isolator, another died after inoculation of a pathogenous $E$. coli strain and the three others were conventionalized.

\title{
ÉTUDE DE LA STRUCTURE FINE DU GLUCIDE DE RÉSERVE DU PROTOZOAIRE « GREGARINA BLABERAE »
}

\author{
Christiane MERCIER \\ Station de Biochimie et Physico-Chimie des Céréales, \\ C.E.R.D. I. A. I. N. R. A., \\ 91305 Massy
}

Le glucide de réserve du protozoaire Gregarina blaberae, parasite des Invertébrés, a été identifié, selon la littérature, à de l'amidon, par son aspect physique (taille et forme), sa biréfringence en lumière polarisée et son insolubilité dans l'eau froide. La coloration de son complexe avec l'iode lui confère par contre la structure du glycogène ; ce qui explique les divers noms utilisés pour désigner ce glucide ; paraglycogène, zooamylon, glycogène, le terme de paraglycogène étant le plus courant chez les grégarines.

Les travaux de cytochimie et d'ultrastructure effectués récemment par ScHrEvel (1970) sur le glucide isolé du trophozö̈te de grégarine par traitement alcalin sont en faveur d'un glucide du type amylopectine, constituant ramifié de l'amidon.

L'étude de la structure de ce glucide par les méthodes classiques telles que la détermination de la longueur d'onde maximum d'absorption $(\lambda \max )$ de son complexe avec l'iode, de la longueur 
moyenne de ces chaînes constitutives externes et internes par oxydation périodique et de son taux de $\beta$-amylolyse conduisent également à une structure du type amylopectine. Il est à noter cependant que ces différentes déterminations fournissent une valeur moyenne à partir d'une population de molécules qui peuvent varier largement en structure et en longueur de chaînes.

La récente découverte des enzymes spécifiques de la liaison ( $\mathrm{I}-6$ ) des $\alpha$-glucanes, pullulanase (Bender et Wallenfels, 196i) et isoamylase (Gunja-Smith, Marschall, Smith et Whelan, I970) a permis de développer une méthode enzymatique d'étude de la structure fine (MERcier et WHELAN, 1970) ; celle-ci au contraire des méthodes classiques, présente l'avantage de déramifier les chaînes constitutives de l' $\alpha$-glucane sans leur dégradation préalable et d'étudier leur répartition en longueur de chaîne et en nombre, après fractionnement par tamisage moléculaire sur Sephadex G-5o.

Ainsi soumise à l'action successive de la pullulanase, l'isoamylase, la $\beta$-amylase, l'amyloglucosidase et la glucose-oxydase, la structure fine du glucide de Gregarina blaberae a été comparée à celles du glycogène de foie de lapin et de l'amylopectine de plante (Mercier, Schrevel et Stark, 1973).

Bien que les données classiques soient en faveur.du type amylopectine, la répartition des chaînes constitutives du glucide de grégarine est différente de celle du glycogène et de l'amylopectine étudiés. Ce qui lui confère une structure comprise entre ces dernières et semblable à celle du phytoglycogène du maïs doux.

\section{RÉFÉRENCES BIBLIOGRAPHIQUES}

Bender H., Wallenfels K., I96r. Untersuchungen an Pullulan. II. Spezifischer Abbau durch ein bakterielles. Enzym. Biochem. Z., 334, 79-95.

Gunja-smith Zeenat, Marshall J. J., Smith E. E., Whelan W. J., I97o. A glycogen debranching enzyme from Cytophaga. Febs Letters, 12, 96-100.

Mercier Christiane, Schrevel J., Stark J. R., I973. The storage polysaccharide (Paraglycogen) of the gregarine, Gregarina blaberae: Cytology and biochemistry. Comp. Biochem. Phys. (sous presse).

Mercier Christiane, Whelan W. J., I97o. The fine structure of glycogen from type IV glycogen storage disease. Eur. J. Biochem., 16, 579-583.

Schrevel J., 197o. Recherches Ultrastructurales et cytochimiques sur le paraglycogène, réserve glucidique des grégarines et coccidies. J. Microscopie, 9, 593-6ro.

\section{SUMMARY}

\section{STUDY OF THE FINE STRUCTURE \\ OF STORAGE POLYSACCHARIDE OF PROTOZOA, GREGARINA BLABERAE}

Storage polysaccharide of protozoa, Gregarina blaberae, parasite of Invertebrates has been identified according to the literature as starch by its size and spherical form, birefringence under polarized light and insolubility in cold water. Its iodine complex staining in contrast indicates a structure of glycogen type. These characters explain the diverse names proposed to designate this type of polysaccharide : paraglycogen, zooamylon, glycogen, the term of paraglycogen being the most common in Gregarines.

The recent cytochemical and ultrastructural investigations of Schrevel (1970) on paraglycogen isolated from trophozoite of the Gregarine by the use of alkali are in favour of the amylopectin type. 
Study of the paraglycogen structure by classic methods such as determination of the wavelength of peak-absorption $(\lambda \mathrm{max})$ of its iodine complex, the average chain length $(\overline{\mathrm{Cl}})$, outer $(\overline{\mathrm{OCl}})$ and inner $(\overline{\mathrm{ICl}})$ chains by periodic oxidation and the $\beta$-amylolysis rale also lead to the amylopectin type.

However it must be noted that these different determinations are all mean values based on the individual value of the members of a population of molecules which can vary strongly in their structure and their chain length.

The recent discovery of specific enzymes of $\alpha \mathrm{I} \rightarrow 6$ branch linkages in a $\alpha$-glucans, pullulanase (Bender and Wallenfels, 196r) and isoamylase (Gunja-Smith, Marshale, Smith and WhELAN, 1970) has permitted us to develop an enzymic method to study the fine structure of $\alpha$-glucans (MeRCIER and WHELAN, I970). The latter, in contrast with the classic methods, has the advantage of debranching the constitutive chains of the $\alpha$-glucan without any degradation and of allowing the study of their distribution in terms of chain length and number, after fractionating them on Sephadex G-5o.

Thus, submitted to the successive action of pullulanase, isoamylase, $\beta$-amylase, amyloglucosidase and glucose-oxidase, the fine structure of paraglycogen of Gregarina blaberae has been compared to that of rabbit-liver glycogen and plant amylopectin (MERCIER, SCHREVEL and STARK, I973).

Although the results obtained by the classic methods indicate an amylopectin structure, the distribution of constitutive chains of paraglycogen is different from those of glycogen and amylopectin, conferring a structure between these two last ones and similar to that of sweet corn phytoglycogen.

\title{
ÉVOLUTION DE LA MICROFLORE DIGESTIVE DU LAPIN HOLOXÉniQUE DE LA NAISSANCE AU SEVRAgE
}

\author{
$\mathrm{Ph}$. GOUET et G. FONTY \\ Laboratoire de Microbiologie, \\ Centre de Recherches de Clermont Ferrand, I. N. R. A., \\ Theix 63110 Beaumont
}

Nous avons dénombré chez des lapins holoxéniques (conventionnels) nourris avec un aliment lapin, âgés de $7,14,2 \mathrm{I}, 28,42$ et 56 jours, les bactéries cultivables en anaérobiose aux niveaux de l'estomac, de l'intestin grêle, du cæcum et du côlon. La technique anaérobie employée a été celle préconisée par HUNGate. Nous avons ensuite caractérisé les souches isolées de la microflore dominante pour chacun des organes considérés. Les résultats obtenus sont les suivants :

- La vitesse de colonisation de l'estomac, irrégulière, est tributaire de variations individuelles importantes. Le nombre total de bactéries est généralement faible; il tend à augmenter avec l'âge et se stabilise après sevrage entre $10^{4}$ et $10^{6}$ bactéries/gramme de contenu.

- Dans l'intestin grêle l'implantation des bactéries est plus rapide et plus abondante que dans l'estomac. L'amplitude des variations individuelles, importante chez les jeunes lapereaux, s'estompe après sevrage et la microflore se stabilise entre $5.10^{6}$ et $10^{8}$ bactéries/gramme.

- Le cæcum héberge dès la première semaine, une flore abondante $\left(\mathrm{I}^{7}-\mathrm{IO}^{9} / \mathrm{g}\right)$; par la suite, le nombre de bactéries est constamment élevé $\left({ }^{2} \mathrm{O}^{9}-\mathrm{IO}^{10} / \mathrm{g}\right)$ et varie peu suivant $\mathrm{l}^{\prime}$ âge et les échantillons. 